\title{
Prof. John L. Tarpley: treat students as individuals, peers and young colleagues
}

Received: 07 November 2018; Accepted: 30 November 2018; Published: 24 December 2018.

doi: 10.21037 /jovs.2018.11.04

View this article at: http://dx.doi.org/10.21037/jovs.2018.11.04

\section{Editor's note}

We have seen a fast track of growth in surgical skills and techniques across the broad medical disciplines in recent years. This is tailed after by the repeatedly highlighted and renewed concepts such as minimally invasive surgery, medical artificial intelligence, precision medicine and multidisciplinary team. With an aim to exchange the vast knowledge across borders and expedite studies in cuttingedge surgical practices, the American College of Surgeons (ACS) Clinical Congress 2018 was held in Boston, USA on October 21-25, 2018. Bringing together multi-disciplined surgeons, surgery residents, medical students and wellexperienced surgical teams from all over the world, this Congress sparked a whole bunch of ideas that is believed to benefit more and more patients all over the world.

Taking this golden opportunity, fournal of Visualized Surgery (7OVS) is honoured to interview Prof. John L. Tarpley, Professor of Surgery and Anesthesiology Emeritus, Vanderbilt University, who will share with us his insights of cultural awareness, his own story of becoming a surgeon, his experience of providing medical care and education in Ogbomoso, Nigeria (Figure 1).

\section{Expert's introduction}

Dr. John L. Tarpley attended undergraduate and medical school at Vanderbilt and trained in surgery at the Johns Hopkins Hospital. He spent 2 years at the NCI, Surgery Branch during residency. Dr. Tarpley is a "general general" surgeon whose first career [1978-1993] was in a tertiary care mission hospital in Ogbomoso, Nigeria, where he directed the training for general practice house officers and helped establish a nursing school. He served several years at the Loch Raven VA in Baltimore and on the Johns Hopkins faculty. He joined the Vanderbilt University Department of Surgery and the Nashville VA in 1993 as Associate Chief, Surgical Service. He directed the Vanderbilt General Surgery Residency program as Program Director from

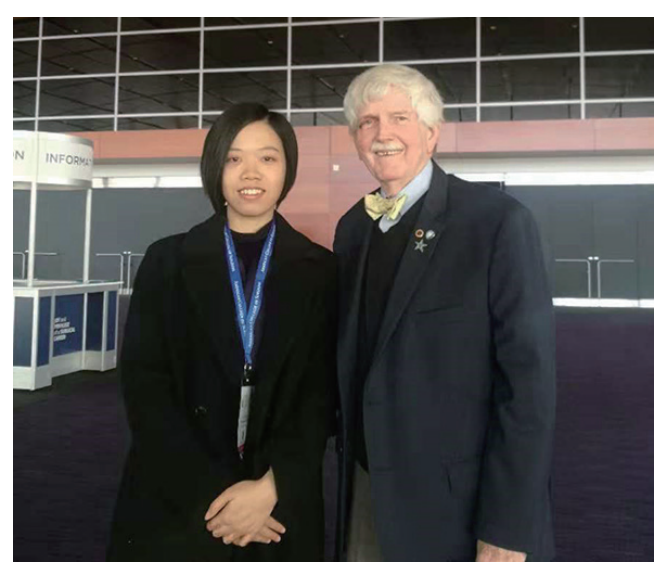

Figure 1 Prof. John L. Tarpley and Editor Miss Silvia Zhou.

1995 to 2014. A professor of surgery and anesthesiology, he is also affiliated faculty in the Vanderbilt Institute for Global Health and helped establish the first ACGMEapproved international rotation for surgery residents. He has co-taught medical school electives in global health, spirituality in medicine, and history of medicine. He has received a number of teaching awards locally and nationally. In 2002 Tarpley received the ACGME's Parker J. Palmer "Courage to Teach" Award and in 2006 the Pfizer-ACS Surgical Volunteerism Award. Tarpley has been actively involved in mentoring medical students and surgical trainees his entire career, particularly those persons interested in teaching and in global health. He served as president of the Association of VA Surgeons and president of the Association of Program Directors in Surgery. The Society for Black Academic Surgeons elected him as an honorary member. Dr. Tarpley is a member of the American College of Surgeons, the West African College of Surgeons, the American Surgical Association, and others. Surgical education, global health, the history of medicine, spirituality in medicine, and clinical surgery especially in the treatment of patients with hernias or esophageal cancer are major areas of interest. 


\section{Interview}

FOVS: You gave a speech about cultural awareness in this Congress, what is the take-home message?

Prof. Tarpley: We can name it as cultural sensitivity, cultural awareness or any other terms. The key is respect. We need to be one person talking to another person, but not somebody up here talking to somebody down there. It is all about mutual respect. We should not look down on people based on their background, language, or their educational level and so on so forth. It is vital to nurture a culture of respect in the field of medicine.

\section{FOVS: What sparked your interest in surgery at the very beginning?}

Prof. Tarpley: My decision in college was whether to be a high school chemistry teacher and a basketball coach versus become a medical doctor. I was the student manager and trainer of an amazing basketball team in college. I taped ankles of players for the trainers of the football and baseball teams as well. I really like sports medicine, a discipline of orthopedics. People who like math and science but not people so much, they may become an engineer or a basic science researcher. If someone likes people more than math and science, they may become a teacher or sociologist. I was interested in science, math and people more than humanities. Obviously, medicine would be a good fit.

\section{FOVS: Why did you choose to be in a tertiary care mission bospital in Ogbomoso, Nigeria in your first career?}

Prof. Tarpley: I was interested in esophageal cancer and lung cancer, and thus, I was supposed to stay in the Johns Hopkins Hospital and put my emphasis on thoracic oncology. However, I read a 1970 letter to the NEMJ that said “...there are some bleeding heart liberals who are marching against the Vietnam War on Saturday but going to country club buffet on Sunday. Why don't some of you folks come over and belp some of these sick folks?" At that time, Baltimore did not need another academic surgeon teaching as much as some areas in Sub-Saharan Africa. So, we went out of a faithbased background through our church. We helped establish a training program in Ogbomoso, Nigeria. Therefore, we went to a low resourced Sub-Saharan country as academic surgeons to capacity build and to help develop capable physicians and surgeons for Nigeria.
FOVS: During the time when you were in Nigeria, you belped establish a nursing school. What encouraged you to do this? How did you do that? What is the status of this school now?

Prof. Tarpley: I was a player in that process but not the school principal or the main driving force, maybe I just took a minor role. I supported it and encouraged the development. One, it provided schooling and potential jobs for a lot of people in the community. Two, we would often have difficulty in having adequate number of nurses. So, having nursing students supplemented our own nurses, which was certainly a workforce addition. Many of them would end up being retained. We also saw a real need for anesthesia. We selected some of the best and the brightest nurse graduates to cultivate and train as nurse anesthetists. It was like a stream, some would proceed to academic medical centers around the country and others would stay with us in Ogbomoso. Thus there was an inflow from the nursing school and outflow to provide safe anesthesia and airway management around the country but always a core four or so with us in Ogbomoso. It was essential to ensure we had a continual production of people who could do a safe airway management and anesthesia. So, it was a nursing school and also a nurse anesthetist training program. Nowadays, the school is still highly functional although it is now 30 or 40 years in existence. I have been in Nigeria every year 1978-2014. The last couple of years I've been more in East, Central, and Southern Africa because Vanderbilt where I spent 31 years as a student and faculty established a Vanderbilt International Surgery elective rotation for our residents. When I was in Nigeria, I attended the West Africa College of Surgeons (WACS) nigh annually. I continued to attend meetings of WACS and visit Nigeria often post relocation to Vanderbilt in 1993 to "water friendships" and retain close contact with colleagues, former residents, friends in Nigeria. I try to get back every year if I can.

\section{FOVS: You bave been actively involved in mentoring medical students and surgical trainees in entire career. What impressed you the most in term of teaching?}

Prof. Tarpley: I think the young people including the students and the residents stimulate and motivate me to learn from them. It is a two-way learning process; they keep me young. They challenge my practice and thoughts with "Why?" questions. The younger folks often have different ideas and ask good questions. They keep me on my toes. Therefore, they are the stimulus and catalyst for me to not 
rest on my oars but to try to continue to do continuing medical education (CME) and continual professional development (CPD) and not be static; to be dynamic rather than static and continue to climb instead of to rest.

\section{FOVS: From your point of view, what are the challenges in education, teaching and training?}

Prof. Tarpley: Speaking of education, I think my job is to provide the smorgasbord or buffet; the students have to bring their appetite. Thus, I would help create the conditions and set the table. I sought to have high expectations of and for them. Doubtless, a good curriculum is essential, but the learners' personal interest, curiosity, and passion are more important. My job is to motivate, stimulate, and catalyze my students throughout the learning process. Treat them as individuals, treat them as younger peers, as younger colleagues. My role is to encourage them to be all they can be, to improve their skills, and to serve their fellow men instead of making money only.

\section{FOVS: Could you introduce some programs you are working now?}

Prof. Tarpley: I retired in the June 2016. We spent 1 year in Kenya and 1 year in Rwanda on capacity-building. I was planning to go back to Kenya in July of 2018, but we had received a request to come to Botswana. My wife is a nonphysician medical educator, librarian, research ninja at finding needed articles, and teammate for 'team tarpley'. We accepted a challenging and important assignment in Botswana to seek develop a surgery residency program for that country. The medical school of the University of Botswana was started in 2008. They had residency programs in internal medicine, family medicine, pediatrics, emergency medicine, and pathology but none in anesthesiology, obstetrics/gynecology, or surgery. They tried to start a surgery residency program in 2012 but did not have the breadth and depth of clinical material nor sufficient faculty or adequate buy-in. Currently, additional young surgeons have been recruited who are quite academic and capable. We hope to spend the next 1 to 3 years seeking to lay the foundation for a surgical residency of quality. We are now gathering ideas, talking with colleagues with the aim to start a surgery residency program for the country of Botswana, a country the size of France or just a bit smaller than the state of Texas but with only a population of 2 million or so which sits just north of the Republic of South Africa.

\section{Acknowledgments}

We would like to express our heartfelt gratitude to Prof. John L. Tarpley for sharing his experience and insights with us. Funding: None.

\section{Footnote}

Provenance and Peer Review: This article was commissioned by the editorial office, Fournal of Visualized Surgery for the series "Meet the Professor". The article did not undergo external peer review.

Conflicts of Interest: Both authors have completed the ICMJE uniform disclosure form (available at http://dx.doi. org/10.21037/jovs.2018.11.04). The series "Meet the Professor" was commissioned by the editorial office without any funding or sponsorship. Both authors reports that they're full-time employees of AME Publishing Company (publisher of the journal). The authors have no other conflicts of interest to declare.

Etbical Statement: The authors are accountable for all aspects of the work in ensuring that questions related to the accuracy or integrity of any part of the work are appropriately investigated and resolved.

Open Access Statement: This is an Open Access article distributed in accordance with the Creative Commons Attribution-NonCommercial-NoDerivs 4.0 International License (CC BY-NC-ND 4.0), which permits the noncommercial replication and distribution of the article with the strict proviso that no changes or edits are made and the original work is properly cited (including links to both the formal publication through the relevant DOI and the license). See: https://creativecommons.org/licenses/by-nc-nd/4.0/.

(Science Editors: Mike Cheung, Silvia Zhou, JOVS, jovs@amepc.org)

doi: 10.21037/jovs.2018.11.04

Cite this article as: Cheung M, Zhou S. Prof. John L. Tarpley: treat students as individuals, peers and young colleagues. J Vis Surg 2018;4:251. 